\title{
Admixture and genetic relationships of Mexican Mestizos regarding Latin American and Caribbean populations based on 13 CODIS-STRs
}

\author{
J. Salazar-Flores ${ }^{\mathrm{a}, 1}$, F. Zuñiga-Chiquette ${ }^{\mathrm{b}, 1}$, \\ R. Rubi-Castellanos ${ }^{c}$, J.L. Álvarez-Miranda ${ }^{\mathrm{b}}$, \\ A. Zetina-Hérnandez ${ }^{\text {b }}$, V.M. Martínez-Sevilla ${ }^{\text {a }}$, \\ F. González-Andrade ${ }^{\mathrm{d}}$, D. Corach ${ }^{\mathrm{e}}$, C. Vullo ${ }^{\mathrm{f}}$, J.C. Álvarez ${ }^{\mathrm{g}}$,
} J.A. Lorente ${ }^{g}$, P. Sánchez-Diz ${ }^{\text {h }}$, R.J. Herrera ${ }^{\mathrm{i}}$, R.M. Cerda-Flores ${ }^{j}$, J.F. Muñoz-Valle ${ }^{\mathrm{k}}$, H. Rangel-Villalobos ${ }^{\mathrm{a}, *}$

a Instituto de Investigación en Genética Molecular, Centro Universitario de la Ciénega, Universidad de Guadalajara (CUCI-UdeG), Av. Universidad \#1115, CP 47810 Ocotlán, Jalisco, Mexico

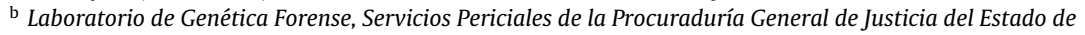
Baja California, BC, Mexico

c Laboratorio de Genética-CIR Biomédicas, Universidad Autónoma de Yucatán (UADY), Mérida, Yucatán, Mexico

d Escuela de Medicina, Universidad Central del Ecuador, Quito, Ecuador

e Servicio de Huellas Digitales Genéticas, Facultad de Farmacia y Bioquímica, Universidad de Buenos Aires, Buenos Aires, Argentina

${ }^{\mathrm{f}}$ Equipo Argentino de Antropología Forense, Independencia 644 - 5C, Edif. EME1, Córdoba, Argentina

${ }^{g}$ Laboratory of Genetic Identification, Department of Legal Medicine, University of Granada, Granada, Spain

h Genomics Medicine Group, Galician Foundation of Genomic Medicine and University of Santiago de Compostela, CIBERER, Santiago de Compostela, Spain

${ }^{i}$ Department of Biological Sciences, Florida International University, Miami, FL 33199, USA

j Facultad de Enfermería, Universidad Autónoma de Nuevo León (UANL), Monterrey, Nuevo León, Mexico

${ }^{\mathrm{k}}$ Instituto de Investigación en Ciencias Biomédicas, Centro Universitario de Ciencias de la Salud,

Universidad de Guadalajara (CUCS-UdeG), Guadalajara, Jalisco, Mexico

\section{A R T I C L E I N F O}

\section{Article history:}

Received 25 August 2013

Accepted 28 August 2014

\section{A B S T R A C T}

Short tandem repeats (STRs) of the combined DNA index system (CODIS) are probably the most employed markers for human identification purposes. STR databases generated to interpret DNA profiles are also helpful for anthropological purposes. In this work,

\footnotetext{
* Corresponding author. Tel.: +52 392 9257112; fax: +52 3929257112.

E-mail address: hrangel13@hotmail.com (H. Rangel-Villalobos).

1 These authors contributed equally to this work.
} 
we report admixture, population structure, and genetic relationships of Mexican Mestizos with respect to Latin American and Caribbean populations based on 13 CODIS-STRs. In addition, new STR population data were included from Tijuana, Baja California (Northwest, Mexico), which represents an interesting case of elevated genetic flow as a bordering city with the USA. Interpopulation analyses included CODIS-STR data from 11 Mexican Mestizo, 12 Latin American and four Caribbean populations, in addition to European, Amerindian, and African genetic pools as ancestral references. We report allele frequencies and statistical parameters of forensic interest (PD, PE, Het, PIC, typical PI), for 15 STRs in Tijuana, Baja California. This Mexican border city was peculiar by the increase of African ancestry, and by presenting three STRs in Hardy-Weinberg disequilibrium, probably explained by recurrent gene flow. The Amerindian ancestry in Central and Southeast of Mexico was the greatest in Latin America (50.9-68.6\%), only comparable with the North of Central America and Ecuador (48.8-56.4\%), whereas the European ancestry was prevalent in South America (66.7-75\%). The African ancestry in Mexico was the smallest (2.2-6.3\%) in Latin America ( $\geq 2.6 \%$ ), particularly regarding Brazil (21\%), Honduras (62\%), and the Caribbean (43.2-65.2\%). CODIS-STRs allowed detecting significant population structure in Latin America based on greater presence of European, Amerindian, and African ancestries in Central/South America, Mexican Mestizos, and the Caribbean, respectively.

(c) 2014 Elsevier GmbH. All rights reserved.

\section{Introduction}

The microsatellites or short tandem repeats (STRs) have demonstrated to be useful for linkage and segregation analyses, and human and non-human (e.g. dogs and cattle) identification. This is due to their elevated heterozygosity, genome abundance, high mutation rate, and simple analysis based on the polymerase chain reaction (PCR) (Butler, 2006). For anthropological purposes, their high mutation rate allows approaching historical questions such as admixture, structure, and migratory events, among others (Wang et al., 2008). Probably, STRs used in forensic and paternity testing are the most commonly employed markers, specifically the core of 13 STRs that comprise the combined DNA index system (CODIS). The inclusion of CODIS-STRs in commercial human identification kits has increased the number of population databases that can be used in molecular anthropology studies (Butler, 2006).

The admixture process presupposes the contact of ancestral populations that have been previously in relative isolation from each other and generated hybrid populations, whereas the population structure implies differences between individuals of one or more populations. This knowledge is essential in tasks such as association mapping, forensic casework, disease susceptibility prediction, wildlife management, and evolutionary studies (Sans, 2000). In Latin-America, hybrid populations have emerged since the European contact with the New World in 1492, and currently reflect a complex genetic structure from old and recent admixture processes (Bryc et al., 2010; Wang et al., 2008). In Mexico, the European colonization began in 1519, when Spaniards arrived to the Southeast; they crossed the current state of Tabasco and settled in Veracruz. After the conquest, about 85\% of the Spaniards remained in conquered territory. Based on historical records, their origins are described as follows: $33 \%$ from Andalusia, 51\% from Leon, Extremadura, the Old and New Castile, $14 \%$ from other regions of Spain, and some foreigners (6.2\%) mainly from Portugal and Genoa, Italy (Grunberg, 2004). In Mexico, in addition to the European component, African ancestry was incorporated subsequently by means of slave trading from various African countries, such as Cabo Verde, Guinea, and Congo (Aguirre-Beltrán, 1989). 
In fact, studies of mitochondrial DNA (mtDNA) suggest that West and West-Central Africa regions are the most important providers of African ancestry in Central America and North America (Salas et al., 2004). Nevertheless, African genes could have also arrived in Mexico by Spanish migrants with Moorish ancestry, which in turn, was a result of the Islamic occupation of Iberian Peninsula (Gerard et al., 2006).

Currently, most of the Mexican population speaks Spanish and is the result of admixture between Spaniards, Native Americans and African populations through approx. 500 years. They are called Mestizos and predominantly disclose the European and Native American components, with low levels of African ancestry (<5\%) (Bryc et al., 2010; Silva-Zolezzi et al., 2009). However, a Mexican Mestizo is defined as a person born in the country, having a Spanish-derived last name, with family antecedents of Mexican ancestors, at least back to the third generation (Sánchez-Serrano, 1996). A tri-hybrid model has been used to explain the biological diversity of Mexican-Mestizos, where specific ancestral components increase in different geographical areas: European in the North, Amerindian in the Center and Southeast, and the African in the coast. This model has been illustrated in a tripolar diagram where the edges are very narrow, indicating a negligible number of individuals "genetically pure" of any of the three ancestries (Gorodezky et al., 2001).

The admixture analysis in Latin America shows a complex genetic structure and high variation of the Amerindian and European components, principally. These studies have included genome-wide SNPs (Silva-Zolezzi et al., 2009; Bryc et al., 2010) and autosomal STRs in different Latin American populations (Godinho et al., 2008; Marino et al., 2006 Wang et al., 2008), and particularly CODIS-STRs in Mexican populations (Rubi-Castellanos et al., 2009a). However, during the last years further STR datasets used in forensic casework have been reported in Mexican-Mestizo populations (Table 1), and the current inter-populational analyses have not included the continental context. In this study, we analyzed the ancestry, structure, and genetic relationship of Mexican Mestizos with respect to Latin America and the Caribbean, based on 13 CODIS-STRs population datasets. For that purpose, we included reference genetic pools representing the European, Amerindian, and African ancestries. In addition, we included new STR genotype data of Tijuana, Baja California (BC), the border city located in the North of Mexico where thousands of migrants pass to the United States of America. Interestingly, this human mobility comes from various countries, principally Mexico but also Salvador, Guatemala, Honduras, Nicaragua, Panama, Costa Rica, and Belize, respectively (Brick et al., 2011). Therefore, Tijuana border city represents an interesting case to analyze gene flow effects in human populations (INEGI, 2010).

\section{Materials and methods}

\section{DNA extraction and genotyping}

DNA was extracted from buccal swabs or peripheral blood by standard phenol-chloroform method from 409 unrelated Mestizos resident of the Tijuana City, Mexico. The individuals signed a written informed consent according to the Helsinki Declaration. We amplified 15 STRs markers (D3S1358, TH01, D21S11, D18S51, D5S818, D13S317, D7S820, D16S539, CSF1PO, vWA, D8S1179, TPOX, FGA, D2S1338 and D19S433) as recommended in the PCR AmpFISTR Identifiler kit (Applied Biosystems, Foster City, CA). The amplicons and reference allelic ladders were analyzed by capillary electrophoresis in the genetic analyzer ABI-PRISM 310. Results were interpreted using the software GeneMapper 3.2.

\section{Statistical analysis}

In the population sample from Tijuana, we estimated the following forensic parameters with the software PowerStats (Tereba, 2001): allele frequencies, heterozygosity (Het), power of discrimination (PD), power of exclusion (PE), polymorphic information content (PIC), typical paternity index (TPI), and minimum allele frequencies (MAF). Furthermore, for each STR we tested the Hardy-Weinberg equilibrium (HWE) and linkage disequilibrium (LD) to check associations between pairs of loci. Fisher exact tests based on 3200 simulations were carried out with the program Genetic Data Analysis (GDA 1.1) for these purposes (Lewis and Zaykin, 2001). Inter-population analysis was based on 13 CODIS-STR datasets including 2221 Mestizos from 11 Mexican populations, 1125 individuals from 
Table 1

Geographic region, abbreviation, sample size and reference of the admixed population analyzed in this study.

\begin{tabular}{|c|c|c|c|}
\hline $\begin{array}{l}\text { Admixed population } \\
\text { Mexico (Region) }\end{array}$ & Abbr. & $\begin{array}{l}\text { Sample } \\
\text { Size }\end{array}$ & Reference \\
\hline Tijuana (Northwest) & Tij & 409 & This study \\
\hline Chihuahua (North Center) & Chi & 162 & Martínez-González et al. (2005) \\
\hline Nuevo León (Northeast) & $\mathrm{NL}$ & 143 & Cerda-Flores et al. (2002) \\
\hline Jalisco (West) & Jal & 200 & Rubi-Castellanos et al. (2009a,b) \\
\hline Nayarit (West) & Nay & 200 & González-Herrera et al. (2010) \\
\hline Guanajuato (Center West) & Gto & 200 & Rangel-Villalobos et al. (2010) \\
\hline Mexico City (Center) & Mex & 200 & Luna-Vázquez et al. (2005) \\
\hline Puebla (Center) & Pue & 200 & Rubi-Castellanos et al., 2009 \\
\hline Veracruz (Center-East) & Ver & 200 & Rangel-Villalobos et al. (2010) \\
\hline Chiapas (South) & Chia & 107 & Sánchez et al., 2005 \\
\hline Yucatán (Southeast) & Yuc & 200 & Rubi-Castellanos et al. (2009a,b) \\
\hline \multicolumn{4}{|l|}{ Central America } \\
\hline Guatemala & Gua & 200 & Martinez-Espín et al. (2006) \\
\hline El Salvador & Sal & 200 & Monterrosa et al. (2006) \\
\hline Honduras1 (Center-South) & Hon 1 & 176 & Matamoros et al. (2008) \\
\hline Honduras2 (Caribbean coast, Black Garifuna) & Hon2 & 198 & Herrera-Paz et al. (2008) \\
\hline Nicaragua & Nic & 151 & Gutiérrez et al. (2011) \\
\hline Costa Rica & $\mathrm{CR}$ & 200 & Rodríguez et al. (2007) \\
\hline \multicolumn{4}{|l|}{ South America } \\
\hline Venezuela & Ven & 45 & Bernal et al. (2006) \\
\hline Colombia & Col & 200 & Porras et al. (2008) \\
\hline Ecuador & Ecu & 200 & González-Andrade et al. (2003) \\
\hline Brazil & Bra & 200 & Fridman et al. (2008) \\
\hline Paraguay & Par & 181 & Martínez-Espin et al. (2003) \\
\hline Argentina & Arg & 200 & Marino et al. (2006) \\
\hline \multicolumn{4}{|l|}{ The Caribbean } \\
\hline Bahamas & Bha & 162 & Budowle et al. (1999) \\
\hline Nueva Providencia & $\mathrm{NP}$ & 221 & Simms et al. (2008) \\
\hline Jamaica & Jam & 160 & Budowle et al. (1999) \\
\hline Trinidad and Tobago & TT & 85 & Budowle et al. (1999) \\
\hline \multicolumn{4}{|l|}{ Ancestral Pools } \\
\hline $\begin{array}{l}\text { From Mexico (Purepechas, Huastecos, Otomíes, } \\
\text { Tepehuas, Amuzgos, Chinantecos, Choles, } \\
\text { Chontales, Huaves, Mixes, Mixtecos, } \\
\text { Mazatecos, Triquis, Zapotecos Zoques, and } \\
\text { Mayas) and Ecuador (Woaranis and Kichuas) }\end{array}$ & Amer & 915 & $\begin{array}{l}\text { González-Martín et al. (2008), } \\
\text { Quinto-Cortés et al. (2010), } \\
\text { Ibarra-Rivera et al. (2008), } \\
\text { González-Andrade et al. (2007) }\end{array}$ \\
\hline \multicolumn{4}{|l|}{ European } \\
\hline From Iberian Peninsula (Spain and Portugal) & Eur & 642 & $\begin{array}{l}\text { Camacho et al. (2007), Coudray et al. } \\
\text { (2007), Lopes et al. (2009) }\end{array}$ \\
\hline \multicolumn{4}{|r|}{ (2) } \\
\hline $\begin{array}{l}\text { From West Africa (Guinea Bissau, Equatorial } \\
\text { Guinea, and Angola) }\end{array}$ & Afr & 265 & Calzada et al. (2005), Alves et al. (2005) \\
\hline
\end{tabular}

six Central-American populations, 1026 persons from six South-American populations, and 628 individuals from four Caribbean populations (Table 1, Fig. 1). In addition, we included into the analysis genetic datasets representing the three main ancestral components in Latin American populations: Amerindian, European and African (Table 1).

The software Arlequin 3.5.1.3 (Excoffier and Lischer, 2010) and the aforementioned population databases were employed to perform pairwise comparisons, Analysis Molecular of Variance (AMOVA), and $F_{\mathrm{ST}}$ genetic distances were plotted by multidimensional scaling (MDS) with optimum stress of 0.01 using the program SPSS 10.0 for Windows. In addition, genetic distances of Nei (1978) were estimated with the software GDA 1.1, and were represented in a neighbor joining (NJ) tree by means of TreeView 3.2 (Page, 1996). Different population groups were established considering genetic and geographical criteria using the software SAMOVA 1.0 (Dupanloup et al., 2002). The coordinates (longitude and latitude) were obtained in Google earth (http://www.google.com/intl/es/earth/index.html). The 


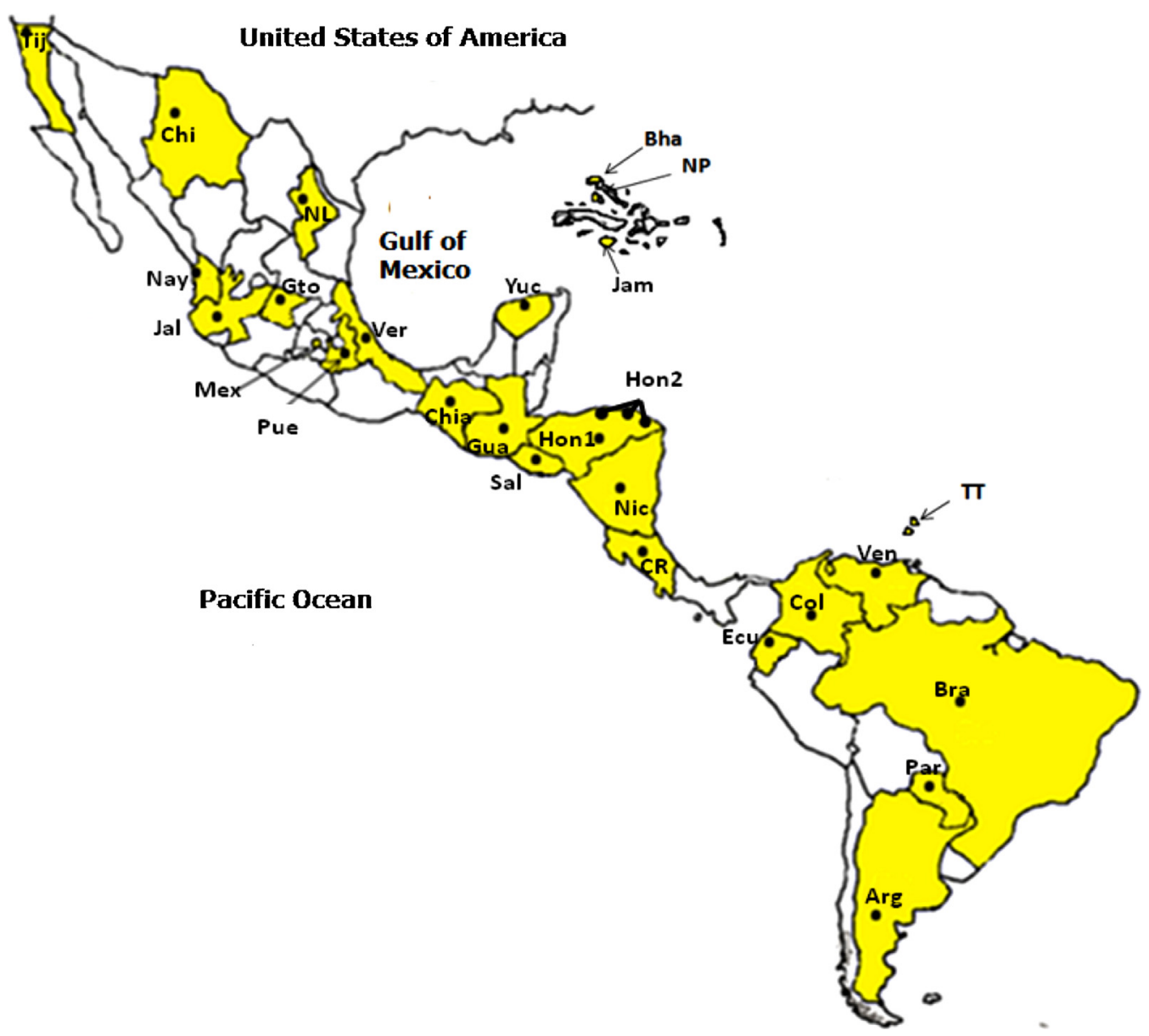

Fig. 1. Geographic location of the Mexican, Central America, South American, and Caribbean populations analyzed here. Shadow areas indicate the Mexican states and countries included in this study. Abbreviation meaning can be consulted in Table 1 .

components of admixture were estimated in individuals and populations with the software Structure 2.3.3 (Falush et al., 2003), with a burn-in-period of 10,000 iterations in each parameter and 25 repetitions for each run (K), using the mixture model, allele frequency correlation, and $\alpha$-value separated for populations, with three populations groups identified as the ancestral references (supervised analysis).

\section{Results}

\section{Genetic relationships}

Genetic distances and pairwise comparisons were estimated between all Mexican-Mestizo, Central American, South American, and Caribbean populations (Suplementary Table 1). Nei and $F_{\mathrm{ST}}$ distances were represented in a NJ tree and a MDS plot, respectively (Fig. 2A and B). In Mexico, the almost perfect similarity ( $p>0.0019$; after Bonferroni correction) between populations from the same region is noticeable when they are separated into Northwest and Central-Southeast regions, and differentiation between populations from the opposite region is visible, supporting the existence of two consistent population clusters of Mexican-Mestizos (Fig. 2A). In Central America, Honduras2 (Black Garifuna), 

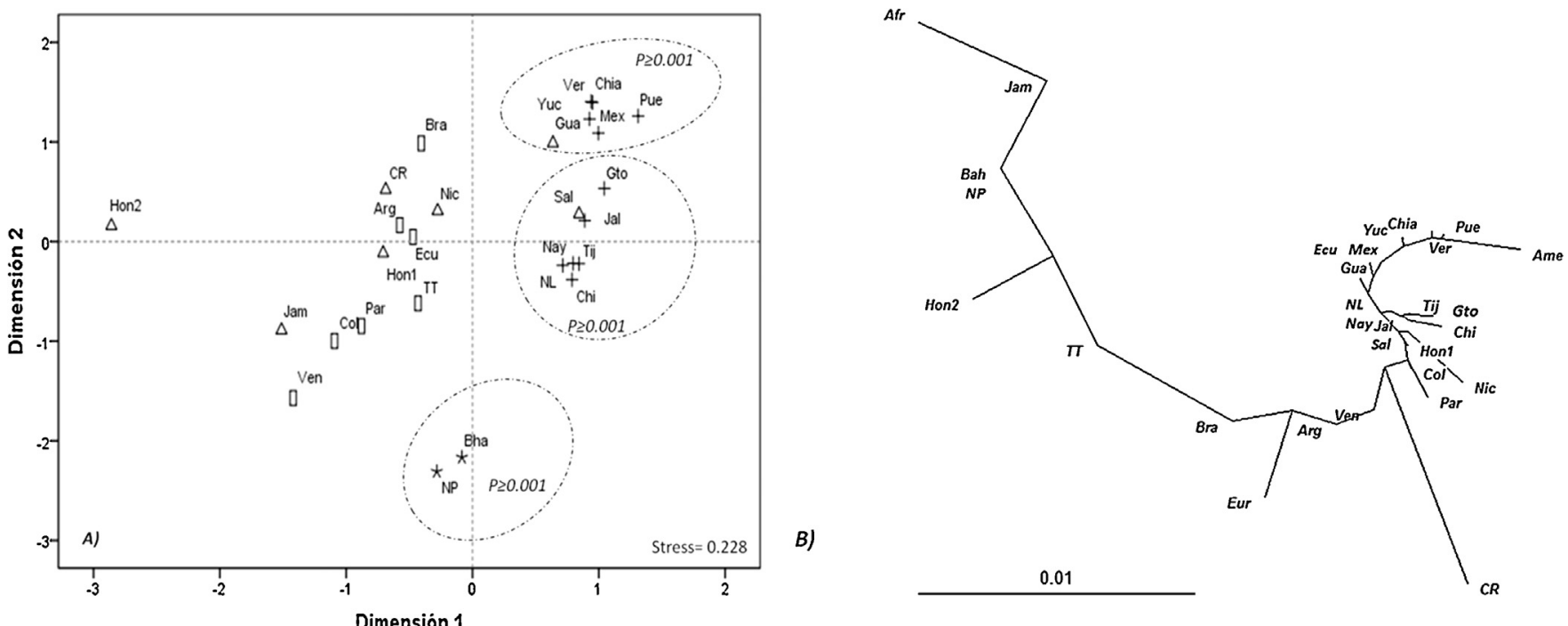

F. 2. (A)MDS plot of $F_{S T}$ genetic distances among Mexican (+), Central America $(\Delta)$, South American( $\square$ ), and Caribbean (") populations. Significant clusters are indicated between Mex populations, as well as two Caribbean populations. (B) NJ tree based on Nei's genetic distances between populations from Mexico, Central America, South American, the Caribbean, and ancestral references (Afr, Eur, Ame). For abbreviations' meaning consult Table 1. 
Table 2

Population structure analyses (AMOVA) based on 13 CODIS-STRs in Mexico, Central America, South America and The Caribbean. ${ }^{a}$

\begin{tabular}{|c|c|c|c|c|c|}
\hline AMOVA & Pop & Groups & Into populations $F_{\mathrm{IT}}(\%)$ & \multicolumn{2}{|c|}{ Between groups $F_{\mathrm{ST}}(\%)$} \\
\hline Mexico & 11 & 1 & 99.48 & \multicolumn{2}{|c|}{$F_{\mathrm{ST}}=0.52 ; p=0.0000$} \\
\hline Central America & 6 & 1 & 96.58 & \multicolumn{2}{|c|}{$F_{\mathrm{ST}}=3.42 ; p=0.0000$} \\
\hline South America & 6 & 1 & 99.28 & \multicolumn{2}{|c|}{$F_{\mathrm{ST}}=0.72 ; p=0.0000$} \\
\hline The Caribbean & 4 & 1 & 99.78 & \multicolumn{2}{|c|}{$F_{\mathrm{ST}}=0.22 ; p=0.0009$} \\
\hline SAMOVA (Mexico) & Pop & Groups & Into populations $F_{\mathrm{IT}}(\%)$ & Between groups $F_{\mathrm{CT}}(\%)$ & $\begin{array}{l}\text { Between populations } \\
\text { into groups } F_{\mathrm{SC}}(\%)\end{array}$ \\
\hline $\begin{array}{l}\text { Nuevo Leon + Chihuahua + } \\
\text { Nayarit vs. Mexico City + } \\
\text { Guanajuato + Jalisco + Veracruz } \\
\text { vs. Chiapas vs. Yucatan vs. } \\
\text { Tijuana vs. Puebla }\end{array}$ & 11 & 6 & $99.60 ; p=0.00587$ & $0.55 ; p=0.00000$ & $-0.15 ; p=0.32845$ \\
\hline
\end{tabular}

a Results of Spatial Analysis Molecular of Variance (SAMOVA) in Central America and South America and The Caribbean are not presented here because they have not shown congruent population clusters.

Costa Rica, and Nicaragua presented differences from all Latin American populations included in this study, and this was more evident for Costa Rica and Honduras2 in the NJ tree (Fig. 2B). Moreover, Guatemala, Salvador and Honduras1 were similar among each other and to some Mexican-Mestizo populations $(p>0.01)$ (Supplementary Table 1$)$. In South America, most of the comparisons were significant $(p<0.0019)$, except Venezuela that was similar to Colombia, Brazil, and Argentina $(p>0.01)$. However, this finding could be the result of the small population sample size of Venezuela $(n=45)$. Among the Caribbean populations, similarity was observed among Bahamas, New Providence and Jamaica, whereas the geographically more distant Caribbean population of Trinidad and Tobago was different from all the populations studied here.

\section{Population structure}

Analysis molecular of variance (AMOVA) showed a low but significant inter-population variability $(p \leq 0.0009)$. In this study, the greater population structure was detected in Central America $\left(F_{\mathrm{ST}}=3.42 \%\right)$, regarding South America, Mexican Mestizos and the Caribbean $\left(F_{\mathrm{ST}}=0.72,0.52\right.$ y $0.22 \%$, respectively). In Mexican Mestizos, the inclusion of genetic and geographic criteria to cluster populations sequentially by means of the SAMOVA tests, showed in the first clusters the separation of southeastern populations (data not shown). The most congruent population structure, characterized by significant differences between populations of different groups, but not between populations of the same group, indicated the existence of two main clusters: (1) North and West: Chihuahua, Nuevo León, and Nayarit; and (2) West and Center: Jalisco, Guanajuato, Mexico City and Veracruz. The rest of Mexican Mestizo populations - principally from the Southeast - remained isolated (Tijuana, Puebla, Chiapas, and Yucatán) (Table 2). In Central America, South America and the Caribbean, SAMOVA test failed to obtain congruent population clusters; only there were evident the most differentiated populations: Costa Rica and Honduras2 in Central America; Brazil and Ecuador in South America; and Trinidad and Tobago in the Caribbean (data not shown).

\section{Admixture components}

In Mexican Mestizos, the European ancestry increases to the Northwest, and vice versa the Amerindian counterpart increases to the Southeast, whereas the African ancestry is low and constant throughout the Mexican territory (2.2-6.3\%) (Fig. 3A). Conversely, in Central America has been partially shown that the European ancestry increases to the South, whereas the Amerindian ancestry increases to the North (Fig. 3A and B). However, Honduras2 and Nicaragua were the two major exceptions from the aforementioned pattern due to the sudden increment of African ancestry (13.6-62\%). In South America, the European ancestry was prevalent (66.7-75\%) but there were two exceptions: (1) 

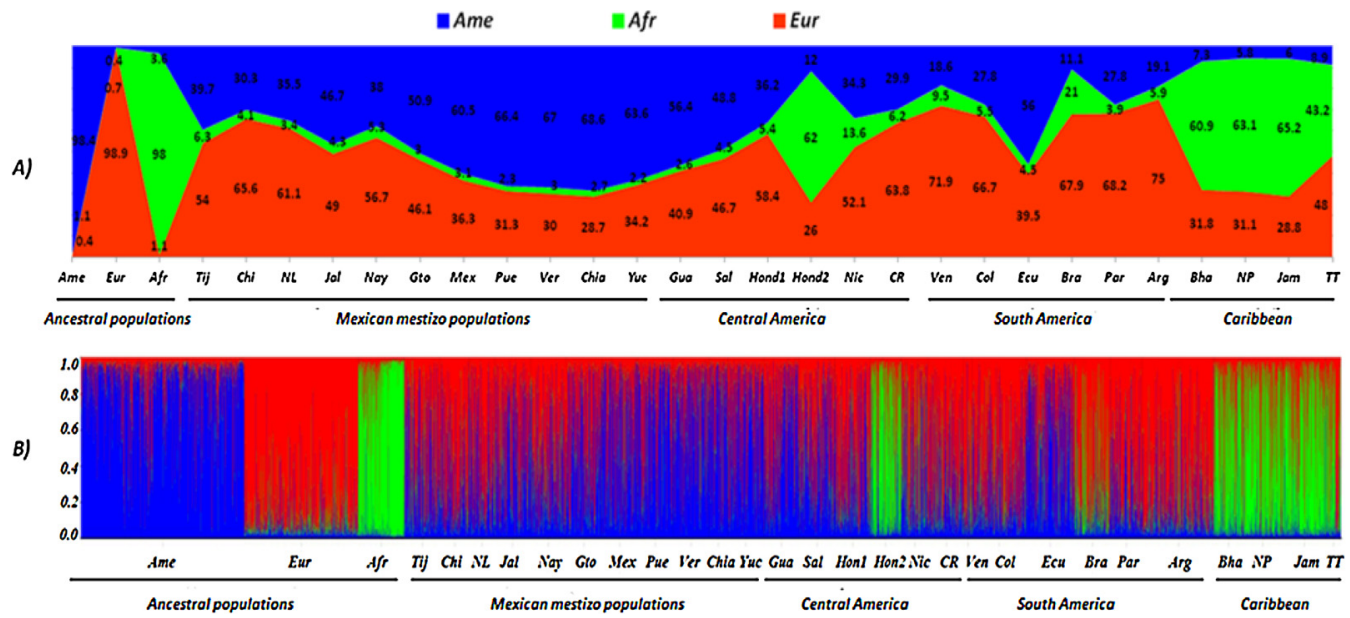

Fig. 3. (A) Admixture components $(k=3)$ estimated in populations from Mexico, Central America, South America, the Caribbean, and ancestral references: Amerindian (Ame), African (Afr), and European (Eur). (B) Supervised analysis with STRUCTURE to obtain ancestry estimates in Latin American and Caribbean populations. Individual ancestry is represented in vertical bars. Abbreviation meaning can be consulted in Table 1.

Ecuador with elevated Amerindian ancestry (56\%), similar to some Mexican-Mestizo populations, and Guatemala and Salvador in Central America (56.4 and 48.8\% respectively); (2) Brazil with high proportion of African origin (21\%). Finally, contrasting with the aforementioned Latin American populations, the Caribbean was characterized by the African ancestry predominance (43.2-65.2\%) (Fig. 3).

In order to observe the admixture components variation, we plotted the standard deviation of individual ancestry for each population studied here (Fig. 4). For most of the Latin American populations, the standard deviations of Amerindian and European ancestries were relatively homogeneous, about two to three times greater than the standard deviation of the African ancestry, except in Honduras2, Brazil, and Caribbean populations, where the African dispersion was higher (range 0.286-0.375), always at the expense of the Amerindian ancestry (Fig. 4). Interestingly, the population of Tijuana, characterized by elevated gene flow, showed the highest African standard deviation (0.157) among the Mexican-Mestizo populations (range 0.04-0.094). In Central and South America, the standard deviation of African ancestry was heterogeneous by the exceptions aforementioned, whereas all four Caribbean populations showed elevated dispersion of African and European ancestry.

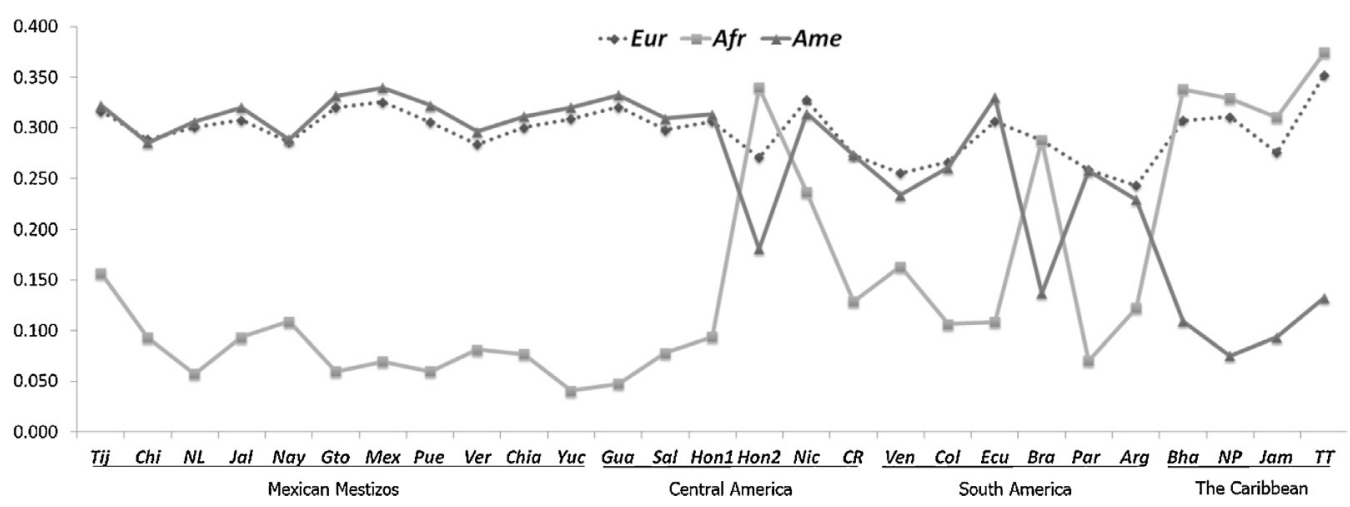

Fig. 4. Standard deviation ( $\sigma$ ) of European (Eur), African (Afr) and Amerindian (Ame) components in populations from Mexico, Central America, South America, and the Caribbean. Abbreviation meaning can be consulted in Table 1 . 
Forensic parameters for the 15 STRs in Tijuana

Allele frequencies and statistical parameters of forensic importance are presented in Table 3 . The STR markers with minor allele diversity $(n=8)$ were D7S820, D16S539, and TPOX, whereas D18S51 displayed the largest number of alleles $(n=22)$. On the other hand, FGA showed the highest values of PD (97.5\%) and PIC (87.5\%), whereas D2S1338 had the largest PE (72.9\%), Het (86.7\%), and TPI (3.7). The 15 STR system showed a combined PD and PE $>99.9999 \%$, with an average heterozygosity of $78.3 \%$ (Table 3). Five STRs were in Hardy-Weinberg disequilibrium $(p<0.05)$, but after applying the Bonferroni correction $(p<0.0033)$ only three loci remained in disequilibrium: TH01, D21S11, and FGA. Although association analysis showed three loci combinations in LD, these cases implied the aforementioned loci in Hardy-Weinberg disequilibrium, which partially explain this finding and does not deserve further discussion (data not shown).

\section{Discussion}

In this work, we analyzed the genetic structure, relationships and admixture components of Mexican-Mestizos based on published CODIS-STR databases from a continental point of view, integrating Latin American and Caribbean populations. When ancestral components are analyzed in hybrid populations, ancestral gene pool references are challenging to obtain because they are part of the past; thus, population geneticists take one or more current populations inhabiting the region that presumably represent each ancestry. Similar previous studies in Mexican-Mestizos with CODIS-STRs and genome-wide SNPs used only one or few populations to represent the European, African and Amerindian ancestries (Rubi-Castellanos et al., 2009b; Silva-Zolezzi et al., 2009). In this study, a larger ancestral gene pool was obtained (Table 1), which theoretically improved the admixture component estimation regarding the previous study with CODIS-STRs (Rubi-Castellanos et al., 2009a).

It is important to note that the focus of this study is the Mexican Mestizo population, and not an analysis of the particular genetic admixture, relationships or structure in Latin American and Caribbean populations. In fact, this analysis is not possible because in most of the cases we included only one population from these countries; however, these issues have been addressed in previous studies (Corach et al., 2010; de Assis Poiares et al., 2010; Marino et al., 2006; Rojas et al., 2010; Wang et al., 2008). Another essential issue is the forensic origin of a large number of population samples, because these commonly include both resident and native individuals from the populations that they represent. Conversely, some population samples include only "native" individuals (e.g. with both parents born in the represented population), which are difficult to obtain and -more importantly- they do not include the variable proportion of recent gene flow received by the population. Therefore, considering the increased human mobility among Mexican urban populations (Valencia-Rojas, 2000), forensic population samples probably represent adequately the current genetic diversity of urban populations, such as those studied herein.

It is important to mention that CODIS-STRs were not designed to estimate ancestral components, unlike admixture informative markers (AIMs), and neither have the power of genome-wide SNPs for that purpose. Consequently, results offer valuable population genetic estimates concerning the human STR diversity. For instance, the generated knowledge facilitates forensic geneticists with a choice of alternative STR databases for Mexican Mestizo populations in order to interpret DNA profiles, when these are not available. However, our preliminary admixture estimates could be helpful in the biomedical area for complex disease analysis (i.e. case-control studies) where population genetic composition and dynamics of the admixture processes should be clearly understood (Parra et al., 1998). Therefore, we can predict that Mestizo or Latin American populations with similar ancestral proportions will have similar prevalence of certain diseases; if this is not observed, we can imply environmental factors, which should be confirmed in each case. For example, we described high Amerindian and African ancestry in Mexico and Jamaica, respectively, but it has been reported that both have high incidence of diabetes mellitus at younger ages (14.4\% and 17.9\%, respectively) (Irving et al., 2011). Finally, the importance of our results in the anthropological field is obvious because they directly contribute to the knowledge of the origin and history of human populations. 
Table 3

Allele frequencies and statistical parameters of forensic importance for 15 STRs (Identifiler kit) in Mexican Mestizos from Tijuana, Baja California State (Northwest), Mexico ( $n=409)$.

\begin{tabular}{|c|c|c|c|c|c|c|c|c|c|c|c|c|c|c|c|}
\hline Allele & D3S1358 & TH01 & D21S11 & D18S51 & D5S818 & D13S317 & D7S820 & D16S539 & CSF1PO & vWA & D8S1179 & TPOX & FGA & D2S1338 & D19S433 \\
\hline 5 & & 0.003 & & & & & & & & & & & & & \\
\hline 6 & & 0.259 & & & & & & & 0.003 & & & 0.006 & & & \\
\hline 6.3 & & 0.005 & & & & & & & & & & & & & \\
\hline 7 & & 0.341 & & & 0.062 & & 0.016 & & 0.005 & & & 0.004 & & & \\
\hline 7.3 & & 0.006 & & & & & & & & & & & & & \\
\hline 8 & & 0.080 & & & 0.006 & 0.083 & 0.088 & 0.007 & 0.007 & & 0.007 & 0.540 & & & \\
\hline 8.3 & & 0.005 & & & & & & & & & & & & & \\
\hline 9 & & 0.107 & & & 0.042 & 0.192 & 0.066 & 0.099 & 0.026 & & 0.010 & 0.048 & & & 0.001 \\
\hline 9.3 & & 0.180 & & & & & & & & & & & & & \\
\hline $\begin{array}{l}10 \\
10.2\end{array}$ & 0.001 & 0.015 & & $\begin{array}{l}0.006 \\
0.001\end{array}$ & 0.058 & 0.112 & 0.256 & 0.180 & 0.239 & & 0.093 & 0.052 & & & 0.003 \\
\hline 11 & & 0.001 & & 0.025 & 0.434 & 0.227 & 0.314 & 0.286 & 0.303 & & 0.081 & 0.220 & & & 0.009 \\
\hline 11.2 & & & & 0.001 & & & & & & & & & & & 0.004 \\
\hline 12 & & & & 0.096 & 0.275 & 0.207 & 0.223 & 0.297 & 0.351 & & 0.111 & 0.129 & & & 0.048 \\
\hline 12.2 & & & & 0.001 & & & & & & & & & & & 0.011 \\
\hline 13 & 0.010 & & & 0.109 & 0.115 & 0.097 & 0.034 & 0.109 & 0.061 & 0.002 & 0.284 & & & & 0.210 \\
\hline 13.2 & & & & 0.001 & & & & & & & & & & & 0.085 \\
\hline 14 & 0.058 & & & 0.178 & 0.007 & 0.077 & 0.004 & 0.020 & 0.006 & 0.073 & 0.274 & 0.001 & & & 0.289 \\
\hline 14.2 & & & & & & & & & & & & & & & 0.053 \\
\hline 15 & 0.416 & & & 0.135 & & 0.004 & & 0.002 & & 0.081 & 0.111 & & & & 0.142 \\
\hline 15.2 & & & & 0.001 & & & & & & 0.005 & & & & & 0.089 \\
\hline 16 & 0.280 & & & 0.114 & & 0.001 & & & & 0.352 & 0.026 & & & 0.032 & 0.041 \\
\hline 16.2 & 0.001 & & & & & & & & & & & & & & 0.014 \\
\hline 17 & 0.141 & & & 0.174 & 0.001 & & & & & 0.262 & 0.004 & & & 0.186 & 0.003 \\
\hline 17.2 & 0.001 & & & & & & & & & & & & & & \\
\hline 18 & 0.083 & & & 0.076 & & & & & & 0.143 & & & 0.009 & 0.078 & \\
\hline 18.2 & & & & & & & & & & & & & 0.003 & & \\
\hline 19 & 0.007 & & & 0.034 & & & & & & 0.072 & & & 0.087 & 0.211 & \\
\hline 19.2 & & & & 0.001 & & & & & & & & & & & \\
\hline 20 & & & & 0.022 & & & & & & 0.010 & & & 0.097 & 0.146 & \\
\hline 20.2 & & & & & & & & & & & & & 0.002 & & \\
\hline 21 & & & & 0.001 & & & & & & & & & 0.112 & 0.037 & \\
\hline 21.2 & & & & 0.001 & & & & & & & & & 0.001 & & \\
\hline 22 & & & & 0.009 & & & & & & & & & 0.143 & 0.058 & \\
\hline
\end{tabular}


Table 3 (Continued)

\begin{tabular}{|c|c|c|c|c|c|c|c|c|c|c|c|c|c|c|c|}
\hline Allele & D3S1358 & TH01 & D21S11 & D18S51 & D5S818 & D13S317 & D7S820 & D16S539 & CSF1PO & vWA & D8S1179 & TPOX & FGA & D2S1338 & D19S433 \\
\hline 22.2 & & & & & & & & & & & & & 0.001 & & \\
\hline 23 & & & & 0.004 & & & & & & & & & 0.116 & 0.131 & \\
\hline 23.2 & & & & & & & & & & & & & 0.001 & & \\
\hline 24 & & & & 0.002 & & & & & & & & & 0.165 & 0.075 & \\
\hline 24.2 & & & 0.001 & & & & & & & & & & & & \\
\hline 25 & & & & & & & & & & & & & 0.113 & 0.034 & \\
\hline 26 & & & 0.001 & & & & & & & & & & 0.093 & 0.007 & \\
\hline 26.2 & & & & & & & & & & & & & 0.001 & & \\
\hline 27 & & & 0.010 & & & & & & & & & & 0.039 & 0.004 & \\
\hline 27.2 & & & 0.002 & & & & & & & & & & & & \\
\hline 28 & & & 0.090 & & & & & & & & & & 0.007 & 0.001 & \\
\hline 28.2 & & & 0.002 & & & & & & & & & & & & \\
\hline 29 & & & 0.201 & & & & & & & & & & & & \\
\hline 29.2 & & & 0.006 & & & & & & & & & & & & \\
\hline 30 & & & 0.329 & & & & & & & & & & 0.005 & & \\
\hline 30.2 & & & 0.006 & & & & & & & & & & & & \\
\hline 31 & & & 0.064 & & & & & & & & & & 0.001 & & \\
\hline 31.2 & & & 0.009 & & & & & & & & & & 0.001 & & \\
\hline 32 & & & 0.023 & & & & & & & & & & 0.003 & & \\
\hline 32.2 & & & 0.119 & & & & & & & & & & & & \\
\hline 33 & & & 0.003 & & & & & & & & & & & & \\
\hline 33.2 & & & 0.045 & & & & & & & & & & & & \\
\hline 34 & & & 0.001 & & & & & & & & & & & & \\
\hline 34.2 & & & 0.002 & & & & & & & & & & & & \\
\hline 36 & & & 0.005 & & & & & & & & & & & & \\
\hline $\mathrm{MAF}^{\mathrm{a}}$ & 0.0069 & 0.0074 & 0.0076 & 0.0078 & 0.0069 & 0.0074 & 0.0077 & 0.0074 & 0.0071 & 0.0071 & 0.0074 & 0.0066 & 0.0076 & 0.0079 & 0.0078 \\
\hline \multicolumn{16}{|c|}{ Statistical parameters of forensic importance } \\
\hline PD & 0.8802 & 0.8998 & 0.9399 & 0.9712 & 0.8787 & 0.9524 & 0.9105 & 0.9101 & 0.8686 & 0.9174 & 0.9333 & 0.827 & 0.9753 & 0.9655 & 0.9513 \\
\hline PE & 0.409 & 0.5927 & 0.6401 & 0.7104 & 0.4541 & 0.6109 & 0.5829 & 0.6027 & 0.5014 & 0.5235 & 0.5981 & 0.316 & 0.6528 & 0.7299 & 0.6888 \\
\hline Het & 0.6873 & 0.7966 & 0.8218 & 0.8578 & 0.7164 & 0.8064 & 0.7912 & 0.8020 & 0.7451 & 0.7579 & 0.7995 & 0.6203 & 0.8284 & 0.8676 & 0.8469 \\
\hline PIC & 0.6752 & 0.7313 & 0.7934 & 0.8657 & 0.6733 & 0.8126 & 0.7371 & 0.7409 & 0.6744 & 0.7376 & 0.7779 & 0.5957 & 0.875 & 0.8492 & 0.8105 \\
\hline TPI & 1.6 & 2.46 & 2.81 & 3.52 & 1.76 & 2.58 & 2.4 & 2.52 & 1.96 & 2.07 & 2.49 & 1.32 & 2.91 & 3.78 & 3.27 \\
\hline $\mathrm{HWE}^{\mathrm{b}}$ & 0.0042 & 0.0002 & 0.0000 & 0.0782 & 0.9543 & 0.0659 & 0.9381 & 0.633 & 0.0702 & 0.1003 & 0.0961 & 0.312 & 0.0006 & 0.4739 & 0.0119 \\
\hline
\end{tabular}

a MAF, minimum allele frequency; PD, power of discrimination; PE, power of exclusion; Het, heterozygosity observed; PIC, polymorphic informativity content; TPI, typical paternity index.

b $p$-value of Hardy-Weinberg equilibrium (HWE) test evaluated with corrected significance level according to Bonferroni $(p<0.0033)$. In italics $p$-values indicating disequilibrium. 


\section{Mexican Mestizo populations}

In Mexico, CODIS-STRs allowed inferring a significant genetic structure similar to that described in the previous study of Rubi-Castellanos et al. (2009a). The clearest picture of this structure was obtained from pairwise comparisons and genetic distances graphically represented (Fig. 2A), which allow suggesting two principal population clusters: Northwest (Tijuana, Chihuahua, Nuevo Leon, Jalisco, Nayarit and Guanajuato) and Center-Southeast (Mexico City, Puebla, Veracruz, Chiapas and Yucatan). However, SAMOVA test pointed out important differentiation of some populations, such as Puebla (Center), Chiapas and Yucatan (Southeast), which could be explained by the higher Amerindian ancestry that characterizes this region. In fact, this finding agrees with the previous proposal stating that the present-day ancestry of Mexican populations approximates the Pre-Hispanic Mesoamerican demography (Rubi-Castellanos et al., 2009a). Conversely, the differentiation observed in Tijuana could be attributable to the increment of allele diversity, result of the increased gene flow. Interestingly, Tijuana displayed the greatest African ancestry, which is probably related to the increasing number of immigrants from Central America passing each year to the USA (Brick et al., 2011). Supporting this interpretation, our results indicate that some Central American populations show greater African ancestry than that observed in Mexico, such as those observed in Honduras, El Salvador, Nicaragua and Costa Rica (Fig. 3). However, Chi-squared test demonstrated that the African ancestry was homogeneous among all 10 Mexican Mestizo populations (Yates $p$-value $=0.9935$ ); thus, we cannot justify a deeper discussion of this finding.

The admixture component pattern obtained in Mexican Mestizo populations is similar to the previously described by genome-wide SNPs and CODIS-STRs (Rubi-Castellanos et al., 2009a; Silva-Zolezzi et al., 2009). However, the African ancestry obtained with CODIS-STRs was lesser than those previously reported. This is explained by software Leadmix employed before for that purpose (Wang, 2003), whereas in this study the program Structure was used (Falush et al., 2003). This program has been selected because results are similar to ancestry estimates based on genome-wide SNPs (Silva-Zolezzi et al., 2009), which are presumably more reliable.

\section{Central America and the Caribbean}

In Central America, population structure was greater than in Mexico, South America and the Caribbean $\left(F_{\mathrm{ST}}=3.42 \%\right.$ vs. $0.52,0.72$ and $\left.0.22 \%\right)$. Interestingly, Mexico shows similarity between populations with elevated Amerindian ancestry (Guatemala, El Salvador and Honduras1), but this gradually decreases to the South (56.4-36.2\%). In addition, Honduras2 (Black Garifuna), Costa Rica, and Caribbean populations were characterized by greater differentiation (Fig. 2A), attributable to greater African component (Fig. 3A). In Costa Rica, historical records describe the large scale arrival of western African workers to build the Atlantic railroad, which explains the increase in African ancestry in this country (Putnam, 2000). In Honduras, the Afro-descendant presence has been constant since the Spanish conquest to the present, in fact, historical records describe the presence of four Afro-descendant towns from the 16th to the 20th century (Amaya, 2002): (i) Black slaves, brought to work in mining areas and states; (ii) Miskito ethnic groups, mixed with runaway slaves and maroons, which could have lead to inbreeding processes, and even promote differentiation between them; (iii) Black Garifuna (represented herein by Honduras (2), who arrived in the late 18th century and extended into the North of Belize, and the South of Nicaragua; and finally (iv) Black English or Creole, who arrived in the country to work in banana companies, not only in Honduras but also in Panama and Costa Rica.

For the Caribbean, our results detect the elevated African genetic legacy received by the populations studied herein, and show a significant differentiation between some of them (Fig. 2, Table 2). The prevalence of African component is attributable to the trans-Atlantic slave trade that entered the Bahamas from West Africa (Duncan et al., 1996). These facts cause that Caribbean people share similarity (up to $83.6 \%$ of their gene pool) to countries such as Angola, Equatorial Guinea, Kenya, and Madagascar, specifically New Providence (Simms et al., 2008). Interestingly, two pulses of African migration to the Caribbean were described in a genomewide population study (Moreno-Estrada et al., 2013): the first pulse representing genetic component more similar to coastal West African regions involved in early stages of the trans-Atlantic slave trade; the second pulse more similar to present-day 
West Central African populations of a later transatlantic deportation. This peculiar admixture process seems to be critical to explain the differences between Caribbean populations, and the inland Latin American populations.

\section{South America}

In South America, pairwise comparisons and genetic distances showed larger population structure than in Mexican Mestizos ( $F_{\mathrm{st}}=0.72 \%$, Fig. $2 \mathrm{~A}$ and B). The unique population that showed similarities with another South American populations was Venezuela (Table supplementary 1), but this is explained by the limited sample size $(n=45)$. Interestingly, the European ancestry is prevalent in all South American populations (66.7-75\%, Fig. 3A and B), excepting in Ecuador where the Amerindian ancestry predominates (56\%), similar to some Mexican populations (Fig. $3 \mathrm{~A}$ and B), such as displayed in the NJ tree (Fig. 2B). Probably this is a result of the greater Pre-Hispanic population present in both Mesoamerica and the Andean Region in South America, as previously described (Wang et al., 2007; Rubi-Castellanos et al., 2009b). That larger Pre-Hispanic population in America historically has been attributed to the presence of agricultural societies that formed chiefdoms and states, such as Olmec, Teotihuacan, Toltec, Maya, Aztec and Inca civilizations (Fiedel, 1992).

\section{Variation of ancestry in Latin American and the Caribbean populations}

In most of the Latin American populations, standard deviations of Amerindian and European ancestries were two to three times larger than the African ancestry, except for Brazil, Honduras2 and Caribbean populations (Fig. 4). In Mexico, it is interesting that Tijuana had elevated dispersion levels for the three ancestries, particularly the African one, which could be the result of the high immigration rate aforementioned (Cornejo-Portugal and Fortuny-Loret de Mola, 2011; Brick et al., 2011). Interestingly, the increased variability in African ancestry observed in the western Mexican populations of Nayarit and Jalisco (Fig. 4), is consistent with a recent study of paternal lineages in Mexico where Jalisco presented the largest African ancestry (8.8\%) (Martínez-Cortés et al., 2012). It is interesting that the increase of African variability (standard deviation) diminished the variability of Amerindian ancestry, whereas European variability remained relatively constant throughout all the American populations studied herein (Fig. 4). This result illustrates the significant European genetic legacy in the current populations of Latin America and the Caribbean. Conversely, the increase of Amerindian ancestry throughout Latin America (Figs. 3 and 4) is closely related with the Pre-Hispanic population densities, as previously claimed (Wang et al., 2008; Rubi-Castellanos et al., 2009). Finally, the time and intensity of African slave trading (Moreno-Estrada et al., 2013) seems to be crucial to delineate the actual distribution of African ancestry in Latin American and Caribbean populations.

\section{Statistical parameters of forensic interest in Tijuana City}

We report allele frequencies and statistical parameters of forensic interest in Tijuana,. The estimated informativity for the 15-STR system is sufficient to solve the majority of forensic and paternity cases in this city. The loci TH01, D21S11, and FGA were in Hardy-Weinberg disequilibrium (Table 3), which explains the subsequent LD in some combinations involving these three STRs. Because in Tijuana City there is not one obvious factor affecting the Hardy-Weinberg equilibrium (i.e. mutation, selection or genetic drift), excepting the elevated gene flow, we think this is the most plausible explanation for these findings, in agreement with the greatest mean number of alleles observed in this city (8.7) compared to the rest of Mexican Mestizo populations (range 5-6.9). Interestingly, Mexico City, the capital of the country - also characterized by elevated gene flow-presented the second most elevated mean number of alleles (6.9). Socio-demographic records regarding the high gene flow in Tijuana include the following: (1) Tijuana, along with San Ysidro Port in the south of San Diego (USA), are one of the most transited sites in the world, with about 55 million crossings of migrants per year (COBBH, 2000); some people who fail crossing the border, finally end as residents of Tijuana. (2) There is also an important immigration of "patients without borders", who eventually are settled in Tijuana looking for health services and motivated by the lack of health insurance, language limitations, and preference for 
Latino physicians of their own culture. (3) The immigration of: (i) medical professionals, surgeons, and nurses to care for USA patients; (ii) tourists traveling for business; (iii) USA retired persons $(\sim 250,000)$ living in the Tijuana-Ensenada coastal corridor (Ramírez de Arellano, 2006; Vargas-Hernández, 2011). This immigration can involve variable periods of time (temporary) or the rest of life (permanent). (4) The aforementioned Tijuana's immigration involves individuals from different nationalities (INEGI, 2010). In brief, the effects here detected in Tijuana that could be attributed to elevated gene flow include Hardy-Weinberg disequilibrium in three of 15 STRs (20\%), increment of the allele diversity and African ancestry. Although it is considered that Hardy-Weinberg disequilibrium in one locus has small effect for estimating the DNA profile frequency (Budowle et al., 1995), in forensic casework this can be handled employing the largest estimates between the observed and expected genotype frequencies in order to be conservative.

In conclusion, the genetic structure previously inferred in Mexican Mestizos by differences in ancestry throughout the country was detailed from a continental landscape. Structure and admixture components were analyzed by means of CODIS-STRs in Latin American and Caribbean populations, which displayed higher levels of European and African ancestries. Conversely, Mexican Mestizos present the greatest Amerindian ancestry, only comparable with Latin American populations with elevated Pre-Hispanic demography. Forensic parameters for 15 STRs were estimated for Tijuana, and gene flow effects were inferred in this border population.

\section{Acknowledgments}

We thank to CONACyT-Mexico the financial support to H. R-V (grant No. 129693) and the postdoctoral fellowship to J. S-F. We thank to Daniel Piñero and Quinto-Cortés et al. (2010) for the STR dataset of Amerindian groups from Oaxaca provided for admixture analysis. The authors report no conflicts of interest.

\section{Appendix A. Supplementary data}

Supplementary data associated with this article can be found, in the online version, at http://dx.doi.org/10.1016/j.jchb.2014.08.005.

\section{References}

Aguirre-Beltrán, G., 1989. La población negra de México, estudio etnohistórico, vol. 2. Fondo de Cultura Económica, S.A. de C.V., Mexico.

Alves, C., Gusmao, L., López-Parra, A.M., Mesa, M.S., Amorim, A., Arroyo-Pardo, E., 2005. STR allelic frequencies for an African population sample (Equatorial Guinea) using AmpFISTR Identifiler and Powerplex 16 kits. Forensic Sci. Int. 148, $239-242$.

Amaya, J.A., 2002. Los chinos de Ultramar en Honduras. Editorial Guaymuras, Colección Códices de Ciencias Sociales, Tegucigalpa, Honduras, 1 st ed.

Bernal, L.P., Borjas, L., Zabala, W., Portillo, M.G., Fernández, E., Delgado, W., Tovar, F., Lander, N., Chiurillo, M.A., Ramírez, J.L., García, O., 2006. Genetic variation of 15 STR autosomal loci in the Maracaibo population from Venezuela. Forensic Sci. Int. 161, 60-63.

Brick, K., Challinior, A.E., Roseblum, M.R., 2011. Mexican and Central American Immigrants in the United States. Migration Policy Institute, Washington, DC.

Bryc, K., Velez, C., Karafet, T., Moreno-Estrada, A., Reynolds, A., Auton, A., Hammer, M., Bustamante, C.D., Ostrer, H., 2010. Colloquium paper: genome-wide patterns of population structure and admixure among Hispanic/Latino populations. Proc. Natl Acad. Sci. U.S.A. 107 (Suppl. 2), 8954-8961.

Budowle, B., Baechtel, F.S., Smerick, J.B., Presley, K.W., Giusti, A.M., Parsons, G., Alevy, M.C., Chakraborty, R., 1995. D1S80 population data in African Americans Caucasians, southeastern Hispanics, southwestern Hispanics, and Orientals. J. Forensic Sci. 40, 38-44.

Budowle, B., Moretti, T.R., Baumstark, A.L., Defenbaugh, D.A., Keys, K.M., 1999. Population data on the thirteen CODIS core short tandem repeat loci in African Americans, U.S. Caucasians, Hispanics, Bahamians Jamaicans, and Trinidadians. J. Forensic Sci. 44, 1277-1286.

Butler, J.M., 2006. Genetics and genomics of core short tandem repeat loci used in human identity testing. J. Forensic Sci. 51, 253-265.

Calzada, P., Suárez, I., García, S., Barrot, C., Sánchez, C., Ortega, M., Mas, J., Huguet, E., Corbella, J., Gené, M., 2005. The Fang population of Equatorial Guinea characterized by 15 STR-PCR polymorphisms. Int. J. Legal Med. 119, 107-110.

Camacho, M.V., Benito, C., Figueiras, A.M., 2007. Allelic frequencies of the 15 STR loci included in the AmplSTR Identifiler PCR amplification kit in an autochthonous sample from Spain. Forensic Sci. Int. 173, 241-245.

Cerda-Flores, R.M., Budowle, B., Jin, L., Barton, S.A., Deka, R., Chakraborty, R., 2002. Maximum likelihood estimates of admixture in northeastern Mexico using 13 short tandem repeat loci. Am. J. Hum. Biol. 14, 429-439. 
COBBH., 2000. Annual Border Health Status Report. California Office of Binational Border Health, California.

Corach, D., Lao, O., Bobillo, C., van der Gaag, K., Zuniga, S., Vermeulen, M., van Duijn, K., Goedbloed, M., Vallone, P.M., Parson, W., de Knijff, P., Kayser, M., 2010. Inferring continental ancestry of argentineans from autosomal Y-chromosomal and mitochondrial DNA. Ann. Hum. Genet. 74, 65-76.

Cornejo-Portugal, I., Fortuny-Loret de Mola, P., 2011. Corrías sin saber adónde ibas" Proceso migratorio de mayas yucatecos a San Francisco, California. Cultura y migración 10, 82-106.

Coudray, C., Calderon, R., Guitard, E., Ambrosio, B., González-Martín, A., Dugoujon, J.M., 2007. Allele frequencies of 15 tetrameric short tandem repeats (STRs) in Andalusians from Huelva (Spain). Forensic Sci. Int. 168, 1-4.

de Assis Poiares, L., de Sá, Osorio, P., Spanhol, F.A., Coltre, S.C., Rodenbusch, R., Gusmão, L., Largura, A., Sandrini, F., da Silva, C.M., 2010. Allele frequencies of 15 STRs in a representative sample of the Brazilian population. Forensic Sci. Int. Genet. 4, 61-63.

Duncan, G., Thomas, E., Gallo, J.C., Baird, L.S., Garrison, J., Herrera, R.J., 1996. Human phylogenetic relationships according to the D1S80 locus. Genetica 98, 277-287.

Dupanloup, I., Schneider, S., Excoffier, L., 2002. A simulated annealing approach to define the genetic structure of populations. Mol. Ecol. 11, 2571-2581.

Excoffier, L., Lischer, H.E.L., 2010. ARLEQUIN suite ver 3.5: a new series of programs to perform population genetics analyses under Linux and Windows. Mol. Ecol. Res. 10, 564-567.

Falush, D., Stephens, M., Pritchard, J.K., 2003. Inference of population structure using multilocus genotype data:linked loci and correlated allele frequencies. Genetics 164, 1567-1587.

Fiedel, S.J., 1992. Prehistory of the Americas, 2nd ed. Cambridge University Press, UK.

Fridman, C., dos Santos, P.C., Kohler, P., García, C.F., López, L.F., Massad, E., Gattás, G.J., 2008. Brazilian population profile of 15 STR markers. Forensic Sci. Int. Genet. 2, 1-4.

Gerard, N., Berriche, S., Aouizerate, A., Dieterlen, F., Lucotte, G., 2006. North African Berber and Arab influences in the western Mediterranean revealed by Y-chromosome DNA haplotypes. Hum. Biol. 78, 307-316.

Godinho, N.M.O., Gontijo, C.C., Diniz, M.E.C.G., Falcaño-Alencar, G., Dalton, G.C., Amorim, C.E.G., 2008. Regionals patterns of genetic admixture in South America. Forensic Sci. Int. Genet. Suppl. Ser. 1, 329-330.

González-Andrade, F., Sánchez, D., González-Solórzano, J., Gascón, S., Martínez-Jarreta, B., 2007. Sex-specific genetic admixture of Mestizos Amerindian Kichwas, and Afro-Ecuadorans from Ecuador. Hum. Biol. 79, 51-77.

González-Andrade, F., Sánchez, D., Martínez-Jarreta, B., 2003. Genetic rofile of the Ecuadorian Mestizo population (EcuadorSouth America) by using the PowerPlex 16 system kit. Forensic Sci. Int. 135, 64-66.

González-Herrera, L., Vega-Navarrete, L., Roche-Canto, C., Canto-Herrera, J., Virgen-Ponce, D., Moscoso-Caloca, G., Cerda-Flores, R.M., 2010. Forensic parameters and genetic variation of 15 autosomal STR Loci in Mexican Mestizo populations from the states of Yucatan and Nayarit. Forensic Sci. J. 3, 57-63.

González-Martín, A., Gorostiza, A., Rangel-Villalobos, H., Acunha, V., Barrot, C., Sánchez, C., Ortega, M., Gené, M., Calderón, R., 2008. Analyzing the genetic structure of the Tepehua in relation to other neighboring Mesoamerican populations. A study based on allele frequencies of STRs markers. Am. J. Hum. Biol. 20, 605-613.

Gorodezky, C., Alaez, C., Vázquez-García, M.N., de la Rosa, G., Infante, E., Balladares, S., Toribio, R., Pérez-Luque, E., Muñoz, L., 2001. The genetic structure of Mexican Mestizos of different locations: tracking back their origins through MHC genes, blood group systems, and microsatellites. Hum. Immunol. 62, 979-991.

Grunberg, B., 2004. El universo de los conquistadores: resultado de una investigación prosopográfica. Signos Históricos, juliodiciembre, núm 012, México. Universidad Autónoma Metropolitana-Iztapalapa, México DF, pp. 94-118.

Gutiérrez, C.C., Loáisiga, J.C., Campos, L.G., Monterrosa, J.C., Morales, J., Inda, F.J., Uriarte, I., Yurrebaso, I., García, O., 2011. Population genetic data for 15 STR loci (PowerPlex 16 kit) in Nicaragua. Forensic Sci. Int. Genet. 5, 563-564.

Herrera-Paz, E.F., García, L.F., Aragón-Nieto, I., Paredes, M., 2008. Allele frequencies distributions for 13autosomal STR loci in 3 Black Carib (Garifuna) populations of the Honduran Caribbean coasts. Forensic Sci. Int. Genet. 3, 5-10.

Ibarra-Rivera, L., Mirabal, S., Regueiro, M.M., Herrera, R.J., 2008. Delineating genetic relationships among the Maya. Am. J. Phys. Anthropol. 135, 329-347.

Instituto Nacional de Estadística y Geografía., 2010. Principales resultados por localidad 2010 (ITER), Mexico.

Irving, R., Tusié-Luna, M.T., Mills, J., Wright-Pascoe, R., McLaughlin, W., Aguilar-Salinas, C.A., 2011. Early onset type 2 diabetes in Jamaica and in Mexico Opportunities derived from an interethnic study. Rev. Inv. Clin. 63, 198-209.

Lewis, P.O., Zaykin, D., 2001. Genetic Data Analysis (GDA): Computer program for the analysis of allelic data version 1.0, http://lewis.eeb.uconn.edu/lewishome/software.html

Lopes, V., Serra, A., Gamero, J., Sampaio, L., Balsa, F., Oliveira, C., Batista, L., Corte-Real, F., Vieira, D.N., Vide, M.C., Anjos, M.J., Carvalho, M., 2009. Allelic frequency distribution of 17 STRs from Identifiler and PowerPlex-16 in Central Portugal area and the Azores archipelago. Forensic Sci. Int. Genet. 4, e1-e7.

Luna-Vázquez, A., Vilchis-Dorantes, G., Aguilar-Ruiz, M.O., Bautista-Rivas, A., Rojo-Nava, A.L., Rios-Barrios, E., Rangel-Villalobos, H., 2005. Population data for 15 loci (Identifiler Kit) in a sample from the Valley of Mexico. Leg. Med. 7, 331-333.

Marino, M., Sala, A., Corach, D., 2006. Population genetic analysis of 15 autosomal STRs loci in the central region of Argentina. Forensic Sci. Int. 161, 72-77.

Martínez-Cortés, G., Salazar-Flores, J., Fernández-Rodríguez, L.G., Rubi-Castellanos, R., Rodríguez-Loya, C., Velarde-Félix, J.S., Muñoz-Valle, J.F., Parra-Rojas, I., Rangel-Villalobos, H., 2012. Admixture and population structure in Mexican Mestizos based on paternal lineages. J. Hum. Genet. 57, 568-574.

Martínez-Espin, E., Fernández-Rosado, F., Alvarez, J.C., Entrala, C., Lorente, J.A., Oviedo de Duarte, M., Villanueva, E., Budowle, B., 2003. Paraguayan population data on the fifteen STR loci included in the PowerPlex 16 kit. J. Forensic Sci. 48, $253-255$.

Martinez-Espín, E., Martínez-Gonzalez, L.J., Fernández-Rosado, F., Entrala, C., Álvarez, J.C., Lorente, J.A., Budowle, B., Ovalle de Monroy, M., 2006. Guatemala mestizo population data on 15 STRs loci (Identifiler Kit). J. Forensic Sci. 51, 1216-1218.

Martínez-González, L.J., Martínez-Espín, E.M., Fernández-Rosado, F., Moguel, M.A., Entrala, C., Álvarez, J.C., Lorente, J.A., Budowle, B., 2005. Mexican population data on fifteen STR loci (Identifiler kit) in a Chihuahua (north central Mexico) sample. J. Forensic Sci. 50, 236-238.

Matamoros, M., Pinto, Y., Inda, F.J., García, O., 2008. Population genetic data for 15 STR loci (Identifiler kit) in Honduras. Leg. Med. 10, 281-283. 
Monterrosa, J.C., Morales, J.A., García, O., 2006. Genetic variation for 15 short tandem repeat loci in a Salvadoran (Central America) population. J. Forensic Sci. 51, 451-452.

Moreno-Estrada, A., Gravel, S., Zakharia, F., McCauley, J.L., Byrnes, J.K., Gignoux, C.R., Ortiz-Tello, P.A., Martínez, R.J., Hedges, D.J., Morris, R.W., Eng, C., Sandoval, K., Acevedo-Acevedo, S., Norman, P.J., Layrisse, Z., Parham, P., Martínez-Cruzado, J.C., Burchard, E.G., Cuccaro, M.L., Martin, E.R., Bustamante, C.D., 2013. Reconstructing the population genetic history of the Caribbean. PLoS Genet. 9 (11), e1003925.

Nei, M., 1978. The theory of genetic distance and evolution of human races. Jpn. J. Hum. Genet. 23, 341-369.

Parra, E.J., Marcini, A., Akey, J., Martinson, J., Batzer, M.A., Cooper, R., Allison, D.B., Deka, R., Ferrell, R.E., Shriver, M.D., 1998. Estimating African American admixture proportions by use of population specific alleles. Am. J. Hum. Genet. 63, $1839-1851$.

Porras, L., Beltrán, L., Ortiz, T., Sanchez-Diz, P., Carracedo, A., Henao, J., 2008. Genetic polymorphism of 15 STR loci in central western Colombia. Forensic Sci. Int. Genet. 2, 7-8.

Putnam, L.A., 2000. La población afro-costarricense según los datos del censo de 2000. Centro de investigaciones históricas de América Central. Escuela de Historia, Universidad de Costa Rica Press, San Pedro.

Quinto-Cortés, C.D., Arriola, L.A., García-Hughes, G., García-López, R., Molina, D.P., Flores, M., Palacios, R., Piñero, D., 2010. Genetic characterization of indigenous peoples from Oaxaca, Mexico, and its relation to linguistic and geographic isolation. Hum. Biol. 82, 409-432.

Ramírez de Arellano, A., 2006. La movilidad de pacientes en el contexto internacional, europeo y español. Revista Española de Economía de la Salud. 5, 32-36.

Rangel-Villalobos, H., Rubi-Castellanos, R., Morales-Vallejo, M.E., Molina-Araujo, V., Licea-Cadena, R.A., Rizzo-Juárez, S., MuñizLozano, F.E., Nuño-Arana, I., Muñoz-Valle, J.F., 2010. Admixture estimates and statistical parameters of forensic importance based on PowerPlex 16 system in Mexican Mestizos from the States of Guanajuato (center) and Veracruz (East). Forensic Sci. Int. Genet. 4, 271-272.

Rodríguez, A., Arrieta, G., Sanóu, I., Vargas, M.C., García, O., Yurrebaso, I., Pérez, J.A., Villalta, M., Espinoza, M., 2007. Population genetic data for 18 STR loci in Costa Rica. Forensic Sci. Int. 168, 85-88.

Rojas, W., Parra, M.V., Campo, O., Caro, M.A., Lopera, J.G., Arias, W., Duque, C., Naranjo, A., García, J., Vergara, C., Lopera, J., Hernández, E., Valencia, A., Caicedo, Y., Cuartas, M., Gutiérrez, J., López, S., Ruiz-Linares, A., Bedoya, G., 2010. Genetic make up and structure of Colombian populations by means of uniparental and biparental DNA markers. Am. J. Phys. Anthropol. $143,13-20$.

Rubi-Castellanos, R., Anaya-Palafox, M., Mena-Rojas, E., Bautista-España, D., Muñoz-Valle, J.F., Rangel-Villalobos, H., 2009a. Genetic Data of 15 autosomal STRs (Identifiler kit) of Three Mexican Mestizo Population samples from the States of Yucatan (Southeast) Jalisco (West), and Puebla (Center). Forensic Sci. Int. Genet. 3, 71-73.

Rubi-Castellanos, R., Martínez-Cortes, G., Muñoz-Valle, J.F., Gonzalez-Martin, A., Cerda-Flores, R.M., Anaya-Palafox, M., RangelVillalobos, H., 2009b. Pre-Hispanic Mesoamerican demography approximates the present-day ancestry of Mestizos throughout the territory of Mexico. Am. J. Phys. Anthropol. 139, 284-294.

Salas, A., Richards, M., Lareu, M.V., Scozzari, R., Coppa, A., Torroni, A., Macaulay, V., Carracedo, A., 2004. The African diaspora: mitochondrial DNA and the Atlantic slave trade. Am. J. Hum. Genet. 74, 454-465.

Sánchez, C., Barrot, C., Ortega, M., González-Martin, A., Gorostiza, A., Corbella, J., Huguet, E., Gené, M., 2005. Genetic diversity of 15 STRs in Choles from northeast of Chiapas (Mexico). J. Forensic Sci. 50, 1499-1501.

Sánchez-Serrano, C., 1996. Mestizaje e historia de la población en México. In: Municio, M., García-Barreno, P. (Eds.), Polimorfismo génico HLA en poblaciones hispanoamericanas. Real Academia de Ciencias Exactas Físicas y Naturales, Madrid, España, pp. 173-193.

Sans, M., 2000. Admixture studies in Latin America: from the 20th to the 21st century. Hum. Biol. 72, 155-177.

Silva-Zolezzi, I., Hidalgo-Miranda, A., Estrada-Gil, J., Fernández-López, J.C., Uribe-Figueroa, L., Contreras, A., Balam-Ortiz, E., del Bosque-Plata, L., Velázquez-Fernández, D., Lara, C., Goya, R., Hernández-Lemus, E., Dávila, C., Barrientos, E., March, S., Jiménez-Sánchez, G., 2009. Analysis of genomic diversity in Mexican Mestizo populations to develop genomic medicine in Mexico. Proc. Natl Acad. Sci. U.S.A. 106, 8611-8616.

Simms, T.M., García, C., Mirabal, S., McCartney, Q., Herrera, R.J., 2008. The genetic legacy of the transatlantic slave trade in the island of New Providence. Forensic Sci. Int. Genet. 2, 310-317.

Tereba, A., 2001. Tools for Analysis of Population Statistics. Profiles in DNA, Promega Corporation, www.promega.com/ geneticidtools/powerstats

Valencia-Rojas, A.J., 2000. La migración indígena a las ciudades. Instituto Nacional Indigenista, México, D.F.

Vargas-Hernández, J.G., 2011. Intercambio transfronterizo de servicios de salud y medicinas en la región de Tijuana y San Diego. Pueblos y Fronteras 10, 303-337.

Wang, J., 2003. Maximum-likelihood estimation of admixture proportions from genetic data. Genetics 164, 747-765.

Wang, S., Lewis, C.M., Jakobsson, M., Ramachandran, S., Ray, N., Bedoya, G., Rojas, W., Parra, M.V., Molina, J.A., Gallo, C., Mazzotti, G., Poletti, G., Hill, K., Hurtado, A.M., Labuda, D., Klitz, W., Barrantes, R., Bortolini, M.C., Salzano, F.M., Petzl-Erler, M.L., Tsuneto, L.T., Llop, E., Rothhammer, F., Excoffier, L., Feldman, M.W., Rosenberg, N.A., Ruiz-Linares, A., 2007. Genetic variation and population structure in Native Americans. PLoS Genet. 3 (11), e185.

Wang, S., Ray, N., Rojas, W., Parra, M.V., Bedoya, G., Gallo, C., Poletti, G., Mazzotti, G., Hill, K., Hurtado, A.M., Camarena, B., Nicolini, H., Klitz, W., Barrantes, R., Molina, J.A., Freimer, N.B., Bortolini, M.C., Salzano, F.M., Petzl-Erler, M.L., Tsuneto, L.T., Dipierri, J.E., Alfaro, E.L., Bailliet, G., Bianchi, N.O., Llop, E., Rothhammer, F., Excoffier, L., Ruiz-Linares, A., 2008. Geographic patterns of genome admixture in Latin American Mestizos. PLoS Genet. 4, e1000037. 